\title{
MODEL KINETIKA PERUBAHAN WARNA LABEL INDIKATOR DARI KLOROFIL DAUN SINGKONG (MANIHOT ESCULENTA CRANTZ)
}

\section{KINETICS MODEL OF COLOUR CHANGES INDICATOR LABEL FROM CHLOROPHYLL CASSAVA LEAVES (MANIHOT ESCULENTA CRANTZ)}

\author{
Eddwina Aidila Fitria*), Endang Warsiki, dan Indah Yuliasih \\ Departemen Teknologi Industri Pertanian, Fakultas Teknologi Pertanian \\ Institut Pertanian Bogor, Bogor, Jawa Barat \\ Email: eddwinafitria@gmail.com
}

Makalah: Diterima 30 Juli 2015; Diperbaiki 3 Juni 2016; Disetujui 20 Agustus 2016

\begin{abstract}
Time Temperature Indicators (TTI) is a smart packaging that important for consumers to know the appropriateness of product through an indicator colour change. Currently, there is no development of the kinetics models at TTI to give information for users about the relationship between colour change indicator and time storage. The objective of this research was to develop a kinetic model of smart label. This label was made from chitosan and PVA were added by chlorophyll extracted from cassava leaves. Indicator label stored at five storage temperatures to check the label performance at temperatures of freezer $\left(-10 \pm 2^{\circ} \mathrm{C}\right)$, refrigerator $\left(2 \pm 3^{\circ} \mathrm{C}\right)$, air conditioning $\left(17 \pm 2^{\circ} \mathrm{C}\right)$, room $\left(25 \pm 2^{\circ} \mathrm{C}\right)$, and hot temperature $\left(50^{\circ} \mathrm{C}\right)$. Parameter was observed in the colour change at the label is the value of ${ }^{\circ}$ hue which show the real colour.The results showed that label indicator changed colour from green to brown. The changes of colour indicator label wouldldarker when stored at high temperatures.The kinetic model of chlorophyll discolouration was developed by Arrhenius equation using ordo 0 and ordo 1. The plot of $\ln k$ value and $1 / T$ has resulted on the equation for kinetic model discolouration label the values of $k=9.22 .10^{10} e^{-15294,7 / T}$ with activation energy of $15.2947 \mathrm{kkal} / \mathrm{mol}$ for ordo 0 and $k=1.81 .10^{12} e$. $19891,9 / \mathrm{T}$ with activation energy of $19.8919 \mathrm{kkal} / \mathrm{mol}$ for ordo 1 . The model could predict the quality change of some product accordance with the kinetic model.
\end{abstract}

Keywords : kinetic model, smart label, chlorophyll

\section{ABSTRAK}

Time Temperature Indicator (TTI) adalah kemasan cerdas yang penting bagi konsumen untuk mengetahui kelayakan produk melalui perubahan warna indikator. Saat ini, tidak ada perkembangan kinetika model TTI untuk memberikan informasi bagi users tentang hubungan antara indikator perubahan warna dengan waktu penyimpanan. Jadi, tujuan dalam penelitian ini adalah untuk mengembangkan model kinetika label cerdas. Label ini terbuat dari kitosan dan PVA yang ditambahkan ekstrak klorofil dari daun singkong. Label indikator disimpan pada lima suhu penyimpanan untuk memeriksa kinerja label yaitu pada suhu freezer $\left(-10 \pm 2^{\circ} \mathrm{C}\right)$, refrigerator $\left(2 \pm 3^{\circ} \mathrm{C}\right)$, $\mathrm{AC}\left(17 \pm 2^{\circ} \mathrm{C}\right)$, suhu ruang $\left(25 \pm 2^{\circ} \mathrm{C}\right)$, dan suhu panas $\left(50^{\circ} \mathrm{C}\right)$. Parameter yang diamati dalam perubahan warna pada label adalah nilai ${ }^{\circ}$ hue yang menunjukkan warna yang sebenarnya. Hasil penelitian menunjukkan bahwa label Indikator berubah warna dari hijau menjadi hijau kecoklatan. Perubahan label indikator akan lebih gelap bila disimpan pada suhu tinggi. Pengembangan model kinetika reaksi perubahan warna label indikator didasarkan pada nilai ${ }^{\circ}$ hue. Perubahan warna klorofil pada label indikator dapat menggunakan persamaan Arrhenius dengan reaksi ordo 0 dan ordo 1. Dari hasil plot nilai ln $\mathrm{k}$ dan 1/T, maka persamaan untuk model kinetika perubahan warna label yang dihasilkan pada ordo 0 adalah $\ln \mathrm{k}=9,22.10^{10} \mathrm{e}$ ${ }_{15294,7 / \mathrm{T}}$ dengan energi aktivasi sebesar $15,2947 \mathrm{kkal} / \mathrm{mol}$ dan ordo 1 adalah $\ln \mathrm{k}=1,81.10^{12} \mathrm{e}^{-1981,9 / \mathrm{T}}$ dengan energi aktivasi sebesar 19,8919 kkal/mol. Model ini dapat digunakan untuk memprediksi penurunan kualitas sebuah produk sesuai dengan kinetika model yang dihasilkan.

Kata kunci : model kinetika, label cerdas, klorofil klrofil

\section{PENDAHULUAN}

Kemasan tidak hanya dilihat sebagai wadah, tetapi mempunyai peranan penting dalam memberikan informasi tentang produk yang dikemas. Terlepas dari itu, fungsi lain dari kemasan adalah sebagai kenyamanan, pemasaran, dan komunikasi. Komunikasi antara konsumen dan produsen diperankan oleh kemasan dalam menampilkan informasi seperti berat bahan, sumber bahan, nilai gizi dan tanggal kedaluwarsa. Inovasi kemasan merupakan salah satu aspek penting dalam pengembangan produk baru. Salah satu perkembangan baru dalam teknologi kemasan yaitu kemasan cerdas. Kemasan cerdas adalah sistem melekat sebagai label, yang dimasukan ke dalam kemasan, atau dicetak ke bahan kemasan untuk memantau kualitas produk (Kerry dan Butler, 2008). 
Kemasan cerdas ini dapat memberikan informasi kepada komsumen mengenai kerusakan produk apabila tidak diperlakukan sesuai syarat penyimpanan dan memberikan informasi lebih rinci seluruh rantai suplai serta distribusi produk, sehingga keamanan produk konsumen lebih terjamin (Nofrida, 2013).

Salah satu bentuk kemasan cerdas adalah TTI (Time Temperature Indicator). TTI adalah kemasan cerdas berupa label yang dapat menginformasikan jika terjadi kesalahan suhu selama penyimpanan produk (Nofrida, 2013). Penelitian tentang TTI telah banyak dilakukan, diantaranya Pacquit et al. (2007) telah membuat matriks polimer berwarna yang sensitif terhadap $\mathrm{pH}$. Responnya ditemukan berkorelasi dengan perubahan populasi mikroba pada ikan. Riyanto et al. (2010) meneliti tentang sensor smart packaging dari khitosan-asetat, PVA dan bromthymol blue (BTB) yang memperlihatkan adanya kecenderungan yang nyata dalam mendeteksi tingkat kebusukan fillet ikan nila. Warsiki et al. (2010) telah meneliti mengenai kemasan antimikrobal dengan bahan aktif ekstak bawang putih. Warsiki dan putri (2012) meneliti tentang label cerdas indikator warna dari pewarna alami dan sintetis serta Nofrida (2013) dan Warsiki et al. (2013) juga telah membuat label cerdas berbahan dasar khitosan dan PVA dengan penambahan pewarna antosianin dan diaplikasikan untuk mendeteksi kerusakan susu pasteurisasi pada kemasan.

Berdasarkan penelitian tersebut, peneliti menggunakan indikator warna untuk mengetahui perubahan mutu produk yang dikemas dengan terjadinya proses degradasi warna pada label indikator. Namun, terdapat kekurangan dari penelitian ini yaitu hanya melihat terjadinya perubahan warna secara visual dan perhitungan respon total perubahan warna tanpa mengkaji lebih dalam tentang permodelan kinetika perubahan warna dengan suhu sehingga dapat memprediksi kualitas pangan dengan melihat terjadinya perubahan warna. Selain itu, indikator warna yang digunakan pada label menggunakan warna "merah" dan mengalami perubahan menjadi "kuning". Biasanya, secara umum konsumen mengindikasikan "hijau" sebagai warna produk segar dan "merah" sebagai produk tidak layak konsumsi. Untuk itu, pengembangan label cerdas masih perlu dilakukan. Salah satunya pengembangan label indikator dengan zat wana hijau yang akan berubah menjadi kuning/coklat serta dilakukan pengembangan model kinetika perubahan warna pada label indikator tersebut. Pewarna alami yang memungkinkan untuk dapat diaplikasikan pada label yang memberikan perubahan warna hijau adalah pigmen berasal dari klorofil.

Klorofil telah lama diketahui dapat dimanfaatkan sebagai pewarna alami. Ketersediaan klorofil di alam sangat besar. Gross (1991) menyatakan kadar klorofil rata-rata daun sebesar 1
$\%$ berdasarkan basis kering. Ketersediaan yang banyak di alam menjadikan klorofil berpeluang sebagai pewarna alami. Klorofil mudah mengalami degragasi warna selama proses pengolahan, hal ini disebabkan karena lepasnya ion $\mathrm{Mg}^{2+}$ pada pusat struktur klorofil. Fenomena ini dapat dimanfaatkan dan diintegrasikan untuk label indikator akibat kerusakan produk karena pengaruh suhu sehingga pewarna ini cocok digunakan sebagai pewarna indikator. Dari berbagai sumber klorofil, Alsuhendra (2004) telah meneliti dan membuktikan bahwa jumlah klorofil tertinggi terdapat pada daun singkong.

Penelitian mengenai permodelan sebelumnya telah banyak dilakukan tetapi permodelan perubahan degradasi klorofil pada label indikator selama penyimpanan belum dikembangkan. Penelitian Dermesonlouoglou et al. (2007) memodelkan kinetika reaksi dari perubahan mutu tomat selama penyimpanan pada suhu dingin sedangkan Goncalves et al. (2011) mengembangkan model kinetika yang dilihat dari degradasi kinetika perubahan warna, vitamin $\mathrm{C}$ dan drip loss brokoli selama penyimpanan isothermal dan non ishotermal. Saxena (2012) telah menggunakan model kinetika untuk mengamati perubahan kualitas bahan pertanian, yaitu perubahan warna pada nangka selama proses pengeringan. Masithoh et al. (2013) juga telah mengembangkan model dengan melihat perubahan kualitas tomat selama penyimpanan. Choi et al. (2014) melakukan penelitian kinetika perubahan warna yang dimodelkan dengan kinetika ordo reaksi 0 dan laju respon waktu dimodelkan dengan persamaan Arrhenius. Berdasarkan uraian diatas maka penelitian ini bertujuan (1) menganalisa kinerja perubahan warna label indikator pada berbagai penyimpanan suhu dan, (2) mengembangkan model kinetika perubahan warna label cerdas.

\section{BAHAN DAN METODE}

\section{Bahan dan Alat}

Bahan baku yang digunakan untuk pembuatan film dalam penelitian ini yaitu khitosan, polivinil alkohol (PVA), dan pewarna klorofil daun singkong (Manihot esculenta crantz). Alat yang digunakan dalam penelitian ini adalah homogenizer, cetakan kaca dengan ukuran $20 \mathrm{~cm} \times 15 \mathrm{~cm}$, magnetic stirrer, shaker, serta cromameter.

\section{Pembuatan Label Indikator Warna Klorofil}

Label indikator dibuat dengan mencampurkan $160 \mathrm{~mL}$ larutan kitosan dan $240 \mathrm{~mL}$ larutan PVA (40:60) serta 1\% gliserol. Pembuatan label tersebut sesuai dengan penelitian yang dilakukan oleh Nofrida (2013). Proses aplikasi pewarna adalah sebanyak $25 \mathrm{~mL}$ pewarna/100 mL larutan film. Pewarna yang digunakan yaitu ekstrak klorofil daun singkong. Pencetakan dilakukan 
setelah pewarna klorofil dicampurkan pada campuran film. Diagram alir pembuatan film dapat dilihat pada Gambar 1.

\section{Pengukuran Nilai ${ }^{\mathbf{h}}$ ue}

Pada penelitian ini, Label disimpan pada 5 suhu yang berbeda, yaitu pada suhu freezer ($\left.10 \pm 2^{\circ} \mathrm{C}\right)$, refrigerator $\left(2 \pm 2^{\circ} \mathrm{C}\right)$, AC $\left(17 \pm 2^{\circ} \mathrm{C}\right)$, suhu ruang $\left(25 \pm 2^{\circ} \mathrm{C}\right)$, dan suhu panas $\left(50 \pm 2^{\circ} \mathrm{C}\right)$. Perubahan warna yang terjadi terhadap film indikator warna selama masa simpan, dilihat secara visual dan dengan melakukan pengukuran dengan cromameter untuk mendapatkan nilai a dan b.

Nilai ohue didapat dihitung dari invers tangen perbandingan nilai $b$ dan a. Nilai ohue merupakan gambaran dari sumbu $360^{\circ}$ dimana daerah kuadran 1 menunjukkan warna kemerahan, daerah kuadran 2 menunjukkan warna kuning hijau, kuadran 3 menunjukkan warna hijau biru dan kuadran 4 menunjukkan warna ungu (Nofrida, 2013). Perhitungan ${ }^{\circ}$ hue dapat dilihat pada persamaan 3 .

${ }^{\circ} \mathrm{Hue}=\tan ^{-1}(\mathrm{~b} / \mathrm{a})$

\section{Pengembangan Model}

Pada penelitian ini, ${ }^{\circ}$ hue dijadikan sebagai parameter perubahan warna indikator. Persamaan 2 dan 3 akan menentukan posisi orde yang terjadi pada degradasi klorofil. Persamaan 2 menunjukkan persamaan dasar kinetika orde 0 dan persamaan 3 menunjukkan kinetika orde 1, secara berurutan (Masithoh et al., 2013).

$Q=Q_{o}-k . t$

$Q / Q_{o}=e^{-k . t}$

$Q$ dan $Q_{0}={ }^{\circ}$ hue saat $\mathrm{t}=\mathrm{t}$ dan $\mathrm{t}=0$

$k=$ konstanta laju reaksi dan $\mathrm{t}=$ waktu

Arrhenius menyatakan bahwa hubungan suhu terhadap reaksi atau perubahan yang terjadi dapat dinyatakan seperti persamaan 4 (Chang, 1990).

$k=k_{0} e^{-E a / R T}$

Dengan $k$ adalah konstanta laju reaksi, $k_{0}$ adalah faktor frekuensi, $E a$ adalah energi aktifasi, $R$ adalah konstanta gas, serta $T$ adalah suhu mutlak. Apabila pada Persamaan 4 diubah menjadi fungsi logaritma maka menjadi persamaan 5 .

$\ln k=\ln k_{0}-E a / R T$

\section{HASIL DAN PEMBAHASAN}

\section{Label Indikator Warna Klorofil}

Label indikator setelah dikeringkan pada suhu $50^{\circ} \mathrm{C}$ selama 30 jam menghasilkan film indikator dengan warna hijau. Pewarna klorofil dari daun singkong memiliki warna hijau yang diaplikasikan pada film. Warna pada label indikator dapat dilihat pada Gambar 2.

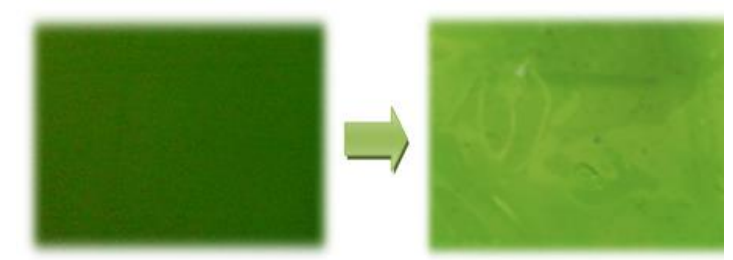

Gambar 2. Label indikator warna klorofil: (a) sebelum dikeringkan (b) sesudah dikeringkan

Dari hasil uji yang dilakukan, secara umum terjadi perubahan warna pada film indikator selama penyimpanan. Perubahan warna yang terjadi yaitu dari hijau menjadi hijau kekuningan hingga kuning kecoklatan. Pada film yang disimpan pada suhu tinggi $\left(50 \pm 2^{\circ} \mathrm{C}\right)$ film mengalami perubahan menjadi kuning kecoklatan secara visual selama 5 jam. Pada suhu ruang $\left(25 \pm 2^{\circ} \mathrm{C}\right)$ mengalami perubahan warna menjadi kuning kecoklatan pada jam ke 7 . Untuk film yang disimpan pada suhu $\mathrm{AC}\left(17 \pm 2^{\circ} \mathrm{C}\right)$ secara visual warna film yang terjadi menjadi hijau kekuningan. Perubahan warna ini terjadi pada jam ke 17. Sedangkan, penyimpanan film pada suhu rendah $\left(2 \pm 2^{\circ} \mathrm{C}\right)$ perubahan warna tidak begitu signifikan secara visual dan berwarna hijau kekuningan (Olive green) pada hari ke 16. Hal yang sama juga terjadi pada label yang disimpan pada suhu freezer ($10 \pm 2^{\circ} \mathrm{C}$ ), perubahan warna yang terjadi dari hijau menjadi hijau kekuningan (Olive green) hingga penyimpanan hari ke 108 .

Perubahan warna film selama masa simpan pada berbagai suhu dapat dilihat pada Gambar 3 . Suhu berpengaruh terhadap perubahan warna label. Semakin rendah suhu penyimpanan maka perubahan warna semakin lambat, sebaliknya semakin tinggi suhu maka perubahan warna label semakin cepat. Hal ini sesuai dengan penelitian yang dilakukan oleh Zabala et al. (2013) yang meneliti tentang label TTI dengan teknologi rotary printing, bahwa label TTI tersebut lebih tahan lama sampai penyimpanan 6 hari pada suhu $278 \mathrm{~K}\left(5^{\circ} \mathrm{C}\right)$ dan 12 jam dengan suhu 293 $\mathrm{K}\left(20^{\circ} \mathrm{C}\right)$.

\section{Nilai ${ }^{\text {hhue }}$}

Nilai ohue merupakan atribut yang menunjukkan derajat warna visual yang terlihat. ${ }^{\circ}$ Hue menyatakan warna sebenarnya seperti merah, hijau, dan kuning. Dari Gambar 3 dapat dilihat, semakin lama penyimpanan maka perubahan warna label menjadi hijau kekuningan (Olive green) hingga kuning kecoklatan pada suhu tinggi dan menghasilkan nilai yang berbeda. setelah mendapatkan nilai a dan b, maka nilai ${ }^{\circ}$ hue didapat dengan menggunakan persamaan $1 .{ }^{\circ} \mathrm{Hue}$ digunakan untuk membedakan warna-warna dan menentukan kemerahan (redness), kehijauan (greenness) dari cahaya. Hubungan lama penyimpanan label terhadap nilai ${ }^{\circ}$ hue dapat dilihat pada Gambar 4. 


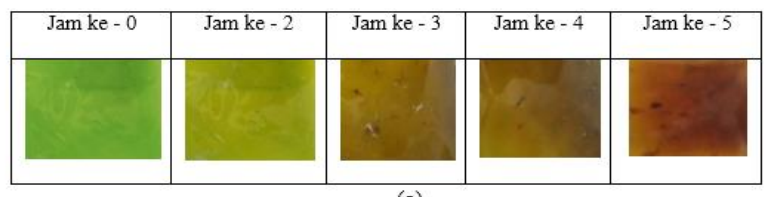

(a)

\begin{tabular}{|c|c|c|c|c|c|c|}
\hline Jam ke-0 & Jam ke -2 & Jam ke - 3 & Jam ke - 4 & Jam ke - 5 & Jam ke - 6 & Jam ke - 7 \\
\hline & & & & & & \\
& & & & & & \\
\hline
\end{tabular}

(b)

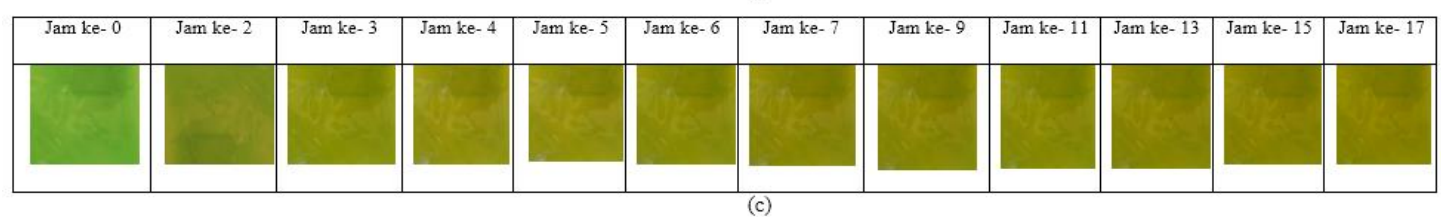

\begin{tabular}{|c|c|c|c|c|c|c|c|c|c|c|}
\hline Hari ke-0 & Hari ke-2 & Hari ke- 3 & Hari ke- 4 & Hari ke- 5 & Hari ke- 6 & Hari ke- 7 & Hari ke- 8 & Hari ke- 9 & Hari ke- 10 & Hari ke-11 \\
\hline & & & & & & & & & & \\
\hline & & & & & & & & & & \\
\hline & & & & & & & & & & \\
\hline
\end{tabular}

(d)

\begin{tabular}{|c|c|c|c|c|c|c|c|c|}
\hline Hari ke-0 & Hari ke - 2 & Hari ke - 4 & Hari ke - 6 & Hari ke- 13 & Hari ke- 18 & Hari ke- 48 & Hari ke- 78 & Hari ke-108 \\
\hline & & & & & & & & \\
\hline & & & & & & & & \\
\hline
\end{tabular}

(e)

Gambar 3. Perubahan warna film indikator warna klorofil pada suhu: (a) $50 \pm 2^{\circ} \mathrm{C}$ (b) $25 \pm 2^{\circ} \mathrm{C}$ (c) $17 \pm 2^{\circ} \mathrm{C}$ $2 \pm 2^{\circ} \mathrm{C}(\mathrm{e})-10 \pm 2^{\circ} \mathrm{C}$
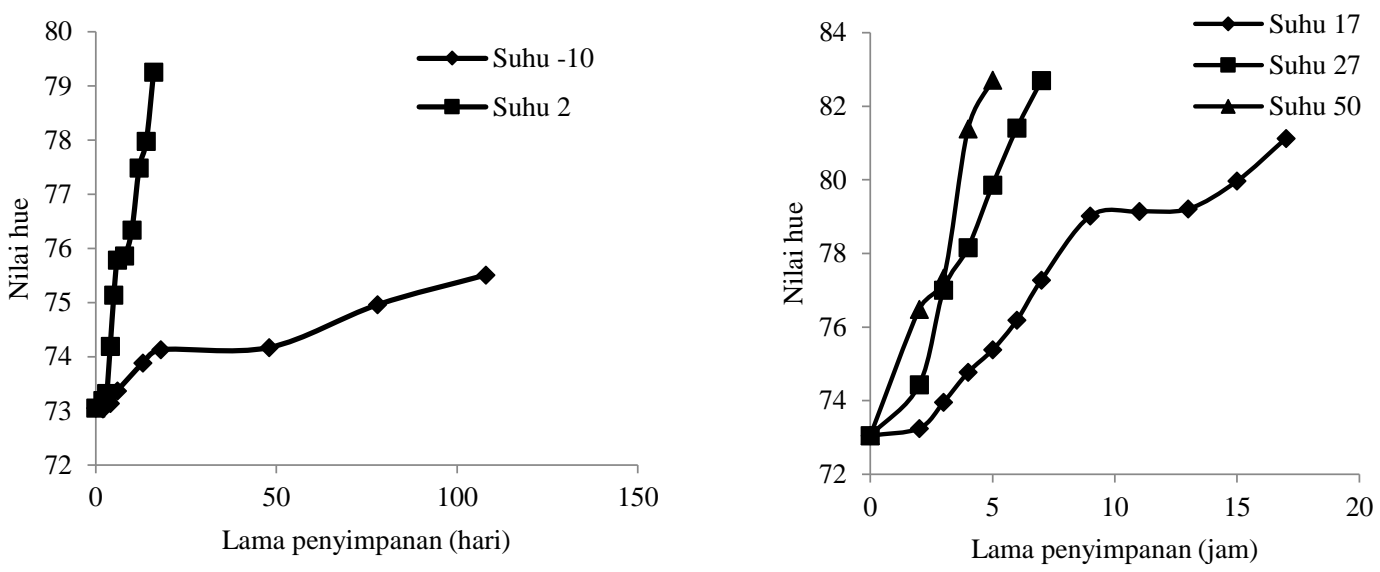

Gambar 4. Hubungan lama penyimpanan terhadap nilai ${ }^{\circ}$ hue

Dari data yang dihasilkan, dapat diketahui bahwa kisaran nilai ${ }^{\circ}$ hue sampel berada pada angka $73^{\circ}$ hingga $83^{\circ}$. Nilai ini terdapat pada kuadran 2 yaitu pada warna hijau menuju hijau kekuningan hingga kuning kecoklatan. Semakin lama penyimpanan maka nilai ${ }^{\circ}$ hue pada masing-masing suhu mengalami peningkatan. Semakin tinggi suhu penyimpanan maka semakin tinggi nilai ${ }^{\circ}$ hue yang menandakan terjadinya perubahan warna. Peningkatan nilai ${ }^{\circ}$ hue juga menandakan kerusakan klorofil pada label. Hal ini menunjukkan bahwa struktur klorofil mengalami degradasi selama penyimpanan pada setiap suhu.

Perubahan warna klorofil pada label terjadi karena klorofil memiliki kelabilan yang ekstrim, seperti sensitif terhadap cahaya ultraviolet, panas, oksigen, dan degradasi kimia. Klorofil dapat terdegradasi secara kimia, yang meliputi reaksi feofitinisasi, reaksi pembentukan klorofilid, dan reaksi oksidasi (Gross, 1991). Pernyataan ini didukung oleh Fennema (1996), bahwa adanya penerapan panas akan mempercepat pembentukan feofitin yang memiliki warna hijau kekuningan 
(olive green). Feofitin adalah salah satu jenis turunan klorofil yang melepaskan $\mathrm{Mg}^{2+}$ dan menggantinya dengan $\mathrm{H}^{+}$. Hal ini dapat terjadi karena $\mathrm{Mg}^{2+}$ merupakan gugus paling lemah pada struktur klorofil yang mudah diserang akibat radikal bebas (Muchtadi, 1992). Hutchings (1994) juga meyebutkan pemanasan berpengaruh terhadap reaksi feofitin yaitu terlepasnya ion $\mathrm{Mg}^{2+}$ pada senyawa klorofil dan disubsitusi oleh ion $\mathrm{H}^{+}$yang menyebabkan berubahnya warna hijau menjadi kecoklatan.

\section{Model Kinetika Perubahan Warna Label Indikator Klorofil}

Berdasarkan nilai o hue maka penentuan orde reaksi dilakukan dengan memplot data ${ }^{\circ}$ hue

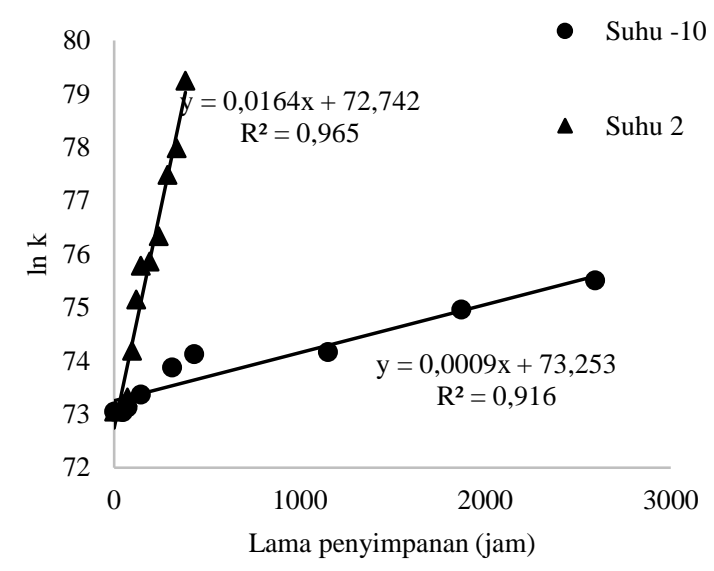

terhadap lama penyimpanan pada masing-masing suhu penyimpanan dengan menggunakan Persamaan 3 dan 4. Berdasarkan plot data tersebut didapat hasil garis linier pada masing-masing ordo. Hasil persamaan dapat dilihat pada Gambar 5 dan Gambar 6.

Arrhenius menyatakan bahwa hubungan suhu terhadap reaksi atau perubahan yang terjadi dapat menggunakan persamaan 4 dan apabila diubah menjadi fungsi logaritma menjadi persamaan 5. Dari hasil plot data pada Gambar 5 dan 6, maka didapat nilai konstanta laju reaksi $(k)$ pada peyimpanan berbagai suhu yang dijabarkan pada Tabel 1 .

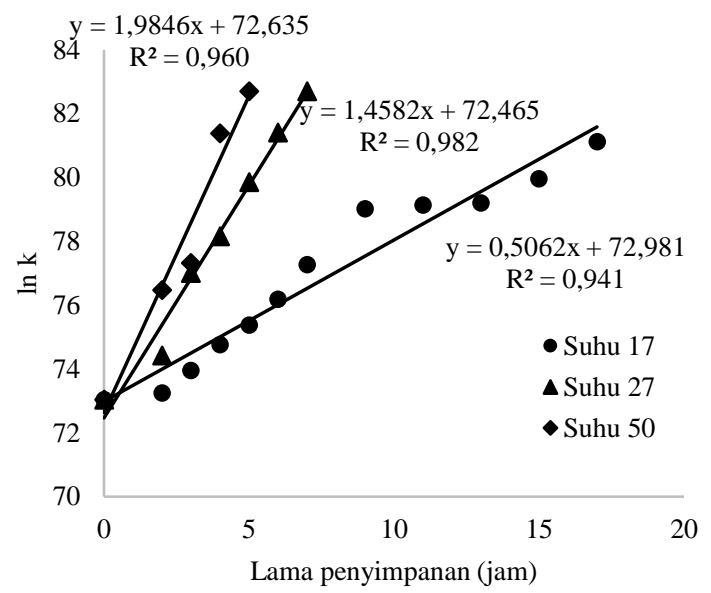

Gambar 5. Hubungan antara nilai ln $k$ dan lama penyimpanan pada berbagai suhu dengan menggunakan ordo 0
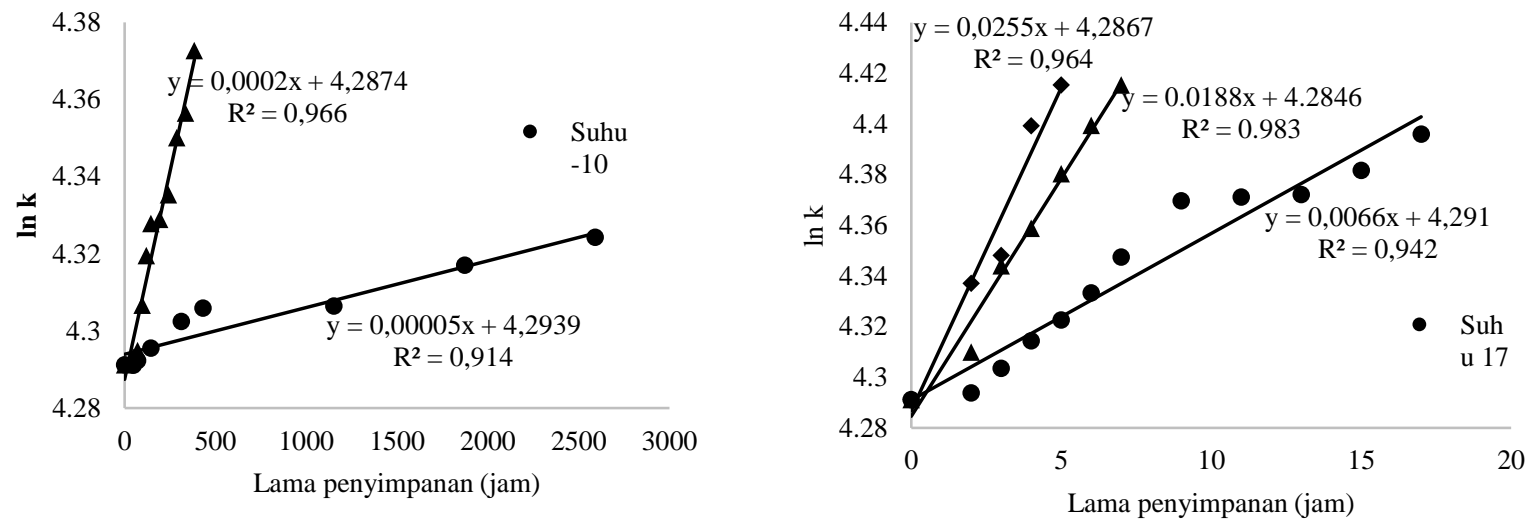

Gambar 6. Hubungan antara nilai ln $k$ dan lama penyimpanan pada berbagai suhu dengan menggunakan ordo 1

Tabel 1. Nilai konstanta laju reaksi $(k)$ dan nilai koefisien korelasi $\left(\mathrm{R}^{2}\right)$ dari ordo 0 dan ordo 1

\begin{tabular}{|c|c|c|c|c|c|c|c|}
\hline \multicolumn{4}{|c|}{ Ordo 0} & \multicolumn{4}{|c|}{ Ordo 1} \\
\hline \multicolumn{2}{|c|}{ Suhu } & \multirow{2}{*}{$k\left(\mathrm{jam}^{-1}\right)$} & \multirow{2}{*}{$\mathbf{R}^{2}$} & \multicolumn{2}{|c|}{ Suhu } & \multirow{2}{*}{$k\left(\right.$ jam $\left.^{-1}\right)$} & \multirow{2}{*}{$\mathbf{R}^{2}$} \\
\hline$\left({ }^{\circ} \mathrm{C}\right)$ & $\left({ }^{\circ} \mathbf{K}\right)$ & & & $\left({ }^{\circ} \mathbf{C}\right)$ & $\left({ }^{\circ} \mathbf{K}\right)$ & & \\
\hline 50 & 323 & 1,985 & 0,960 & 50 & 323 & 0,02550 & 0,964 \\
\hline 27 & 300 & 1,458 & 0,982 & 27 & 300 & 0,01880 & 0,983 \\
\hline 17 & 290 & 0,506 & 0,941 & 17 & 290 & 0,00660 & 0,942 \\
\hline 2 & 275 & 0,160 & 0,965 & 2 & 275 & 0,00020 & 0,966 \\
\hline-10 & 263 & 0,009 & 0,916 & -10 & 263 & 0,00005 & 0,914 \\
\hline
\end{tabular}


Tabel 1 menunjukkan konstanta laju reaksi (k) dan nilai koefisien korelasi $\left(\mathrm{R}^{2}\right)$ dari masingmasing penyimpanan suhu pada ordo 0 dan ordo 1 . Perubahan warna label klorofil pada penelitian ini, dapat menggunakan ordo 0 dan 1. Hal ini dikarenakan, nilai koefisien yang tidak berbeda nyata. Pada penelitian yang dilakukan oleh Amalia (2012) untuk menentukan mutu dipilih parameter yang memilki nilai koefisien korelasi $\left(\mathrm{R}^{2}\right)$ yang cukup besar $(>0,75)$. Untuk mendapatkan energi aktifasi (Ea) dan persamaan perubahan warna label indikator, maka dilakukan dengan membuat plot nilai $1 / \mathrm{T}$ dan $\ln k$. Hasil analisis regresi linier dari plot $1 / \mathrm{T}$ dan $\ln k$ pada ordo 0 didapat persamaan $\mathrm{y}=$ $-7697,4 x+25,247\left(R^{2}=0,910\right)$. Dari persamaan ini diperoleh nilai $E a$ (Energi aktivasi) sebesar 15,2947 $\mathrm{kkal} / \mathrm{mol},(\mathrm{R}=$ nilai tetapan gas $1,987 \mathrm{kal} / \mathrm{mol})$. Persamaan regresi pada ordo 1 adalah $\mathrm{y}=-10011 \mathrm{x}+$ $28,223\left(\mathrm{R}^{2}=0,920\right)$, dengan nilai energi aktivasi sebesar 19,8919 kkal/mol. Energi aktivasi tersebut mempunyai arti bahwa besarnya energi minimal yang dibutuhkan molekul pada label indikator untuk menurunkan pewarna klorofil sebesar 15,2947 $\mathrm{kkal} / \mathrm{mol}$ (pada ordo 0) dan 19,8919 kkal/mol (pada ordo 1). Nilai $k$ diperoleh dari ln $k-7697,4 x(1 / \mathrm{T})+$ 25,247 $\left(\mathrm{R}^{2}=0,910\right)$ pada ordo 0 dan begitu selanjutnya. Hasil plot nilai $1 / \mathrm{T}$ dan $\ln \mathrm{k}$ pada masing-masing ordo dapat dilihat pada Gambar 7.

Degradasi warna label pada penelitian ini mengikuti reaksi ordo 0 dan 1 . Dimana parameter yang digunakan adalah kenaikan nilai ${ }^{\circ}$ hue. Dari hasil plot data pada Gambar 7, maka persamaan untuk model kinetika perubahan warna label indikator dapat dilihat pada Tabel 2.

Tabel 2. Model kinetika perubahan warna klorofil pada label indikator

\begin{tabular}{cl}
\hline Ordo & Model kinetika \\
\hline 0 & $k=9,22.10^{10} e^{-15294,7 / \mathrm{T}}$ \\
1 & $k=1,81.10^{12} e^{-19891,9 / \mathrm{T}}$ \\
\hline
\end{tabular}

Konstanta laju reaksi perubahan klorofil akan semakin besar seiring dengan kenaikan suhu. Uji statistik menunjukkan koefisien determinasi $\left(\mathrm{R}^{2}\right)$

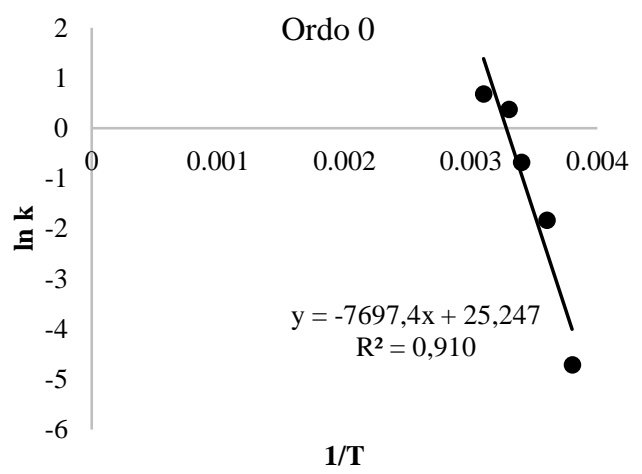

antara nilai logaritma natural $k$ dengan lama penyimpanan menggunakan kinetika yang dikembangkan adalah berkisar antara 0,914-0,983. Penggunakan ordo 0 dan ordo 1 pada persamaan Arrhenius telah banyak dilakukan. Pada penelitian yang dilakukan oleh Amalia (2012), ordo 0 dimanfaatkan untuk menduga umur simpan pada produk nugget ikan dengan merk dagang Fish nugget "so lite". Dasar asumsinya adalah aktifitas mikroba pada berbagai kondisi suhu penyimpanan. Selanjutnya, penggunakan ordo 1 juga dimanfaatkan oleh berbagai peneliti. Renate et al. (2014) membuat model kinetika degradasi capcaisin pada cabai merah giling dengan berbagai kondisi suhu penyimpanan. Masithoh et al. (2013) menyatakan bahwa penurunan karoten, asam sitrat dan kadar vitamin $\mathrm{C}$ pada tomat didekati dengan regresi linier ordo 1. Degradasi warna, vitamin C dan dripp loss pada brokoli juga menggunakan persamaan Arrhenius dengan ordo 1 (Goncalves et al.. 2011). Untuk menentukan perubahan warna klorofil menjadi turunannya, Prangdimurti (2007) juga memanfaatkan reaksi ordo 1 pada penelitian yang dilakukannya.

\section{KESIMPULAN DAN SARAN}

\section{Kesimpulan}

Perubahan warna label dilihat secara visual mengalami perubahan dari hijau menjadi hijau kekuningan hingga kuning kecoklatan. Kisaran nilai ohue sampel berada pada $73^{\circ}$ hingga $83^{\circ}$ dan berada pada kuadan ke 2. Semakin tinggi suhu, maka perubahan warna yang dihasilkan semakin cepat.

Model Arrhenius dapat dimanfaatkan untuk mengembangkan model kinetika perubahan warna klorofil pada label indikator. perubahan warna ini dapat menggunakan ordo 0 maupun ordo 1 dengan parameter nilai ${ }^{\circ}$ hue. Permodelan yang dihasilkan untuk ordo 0 adalah $k=9,22.10^{10} e^{-15294,7 / \mathrm{T}}$ dan untuk ordo 1 adalah $k=1,81.10^{12} e^{-19891,9 / \mathrm{T}}$. Pengembangan model ini dapat digunakan untuk menduga umur simpan label jika disimpan pada kondisi suhu yang berbeda.

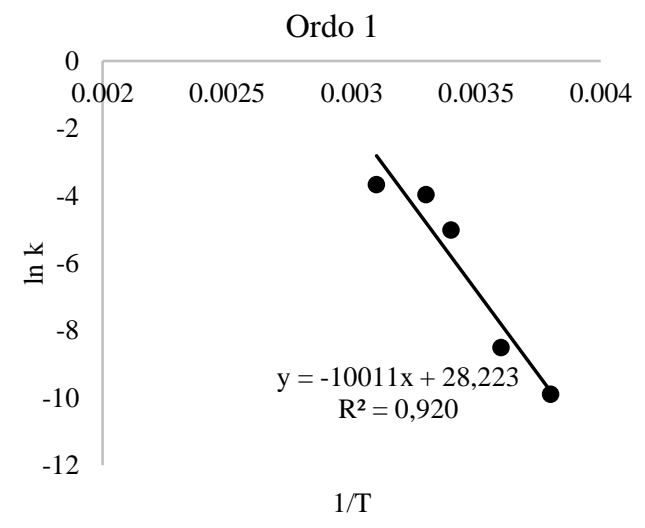

Gambar 7. Plot 1/T dengan ln $k$ untuk perubahan warna pada label indikator 
Saran

Untuk peneliti selanjutnya disarankan dapat menguji label dan produk yang sesuai menghasilkan model hubungan kinetika perubahan warna indikator dengan perubahan mutu produk.

\section{DAFTAR PUSTAKA}

Alsuhendra. 2004. Daya anti-aterosklerosis Zn turunan klorofil dari daun singkong (Manihot esculenta crantz) pada kelinci percobaan. [Disertasi]. Bogor: Institut Pertanian Bogor.

Choi D, Jung S, Kim T, Lee S. 2014. A prototype of time temperature integrator (TTI) with microbeads-entrapped microorganisms maintained at a constant concentration. $J$ Food Eng. 120:118-123.

Dermesonlouoglou E, Giannakourou M, dan Taoukis P. 2007. Kinetic modelling of the degradation of quality of osmodehydrofrozen tomatoes during storage. Food Chem. 103: 985-993.

Fennema OR. 1996. Food Chemistry. $3^{\text {rd }}$ Ed. New York: Marcel Dekker.

Goncalves E, Abreu M, Brando T, Silva C. 2011. Degradation kinetics of colour, vitamin $\mathrm{C}$ and drip loss in frozen broccoli (Brassica oleracea L. Ssp. Italica) during storage at isothermal and non-isothermal conditions. IntRefrig.34: 2136-2144.

Gross J. 1991. Pigments in Vegetables: Chlorophylls and Carotenoids. New York: Van Nostrand Reinhold.

Hutchings J. 1994. Food Colour and Appearance. London: Blakie Academic \& Professional.

Kerry J dan Butler P. 2008. Food Sciece and technology. General and Introductory Food Science and Technology. Smart Packaging Technologies for Fast Moving Consumer Goods. England: John Wiley \& Sons, Ltd.

Masithoh RE, Rahardjo B, Sutiarso L, Harjoko A. 2013. Model kinetika perubahan kualitas tomat selama penyimpanan. J Teknol Pert. 14(1): 21-28.

Muchtadi D. 1992. Petunjuk Laboratoriun Teknologi Pasca Panen Sayuran dan Buah-Buahan. Bogor: PAU Pangan dan Gizi IPB.

Nofrida R. 2013. Film indikator warna daun erpa sebagai kemasan cerdas untuk produk rentan suhu dan cahaya. [Tesis]. Bogor: Institut Pertanian Bogor.
Pacquit A, Frisby J, Diamond D, Lau KT, Farrell A, Quilty B, Diamond D. 2007. Development of a smart packaging for the monitoring of fish spoilage. Ireland: Dublin City University.

Prangdimurti E. 2007. Aktivitas antioksidan dan hiprokolesterolemik ekstrak daun suji (Pleomele angustifolia N.E. Brown). [Disertasi]. Bogor: Institut Pertanian Bogor.

Priyanto G. 1997. Kinetika perubahan mutu saribuah nanas dalam proses aseptik. [Disertasi]. Bogor: Institut Pertanian Bogor.

Riyanto B, Maddu A, dan Hasnedi YW. 2010. Kemasan cerdas pendeteksi kebusukan filet ikan nila. J Pengolah Hasil Perik Indo. 13(2).

Saguy I. 1983. Optimization Method and Applications. Di dalam Saguy (ed.): Computer Aided Techniques in Food Technology. New York: Marchel Dekker.

Sedjati S, Yudiati E, dan Suryono. 2012. Profil pigmen polar dan non polar mikroalga laut Spirulina sp. dan potensinya sebagai pewarna alami. JIK UNDIP. 17(3): 176181.

Saxena A, Maity S, Raju, Bawa A. 2012. Degradation kinetics of colour and total carotenoids in jackfruit (Artocarpus heterophyllus) bulb slice during hot air drying. J Food Bioprocess Technol. doi:10.1007/s11747-010-0409-2.

Warsiki E, Sunarti TC, dan Damanik R. 2010. Pengembangan kemasan antimikrobial untuk memperpanjang umur simpan produk pangan. Prosiding Seminar Hasil Hasil Penelitian IPB 2009, Buku 5 Bidang Teknologi dan Rekayasa Pangan, Bogor: Desember 2010. 579-588

Warsiki E dan Putri CDW. 2012. Pembuatan label/film indikator warna dengan pewarna alami dan sintetis. E-J Agro Indo. 1(2): 82 87

Warsiki E, Nofrida R, dan Yuliasih I. 2013. Pemanfaatan daun erpha (Aervha sanguinolenta) untuk label cerdas indikator warna. JIPI.18(1): 15-19.

Zabala S, Castan J, dan Martinez. 2014. Development of time temperature indicator (TTI) label by rotary printing technologies. Food Control. 50 : 57-64. 